\title{
Biotope and distribution of Blanford's fox
}

\author{
Eli Geffen, Reuven Hefner, David W. Macdonald and Michal Ucko
}

Blanford's fox Vulpes cana has been considered as one of the rarest mammals in south-west Asia. Recently it has been discovered in several locations in the Middle East. The authors conducted a survey of Blanford's foxes in the mountainous desert regions of Israel and found that they are common in Israel, but restricted to a specific habitat. Additional surveys in other Middle Eastern countries are essential for the conservation of this species.

\section{Introduction}

Blanford's fox Vulpes cana is considered to be one of the rarest predatory mammals in southwest Asia (Novikov, 1962). It is seldom represented in scientific collections (Lay, 1967), and trade in its fur is minimal compared with some other fox species (e.g. red and Arctic foxes; Ginsberg and Macdonald, 1990).

Blanford's fox was believed to be confined to mountainous regions in north Iran, Afghanistan, north-west Pakistan and southwest Russia, but recently it has been discovered in Oman, Saudi Arabia, Sinai and Israel. The aims of this paper are to review the distribution of the species and to report on a recent intensive search for it in Israel.

In Pakistan Blanford's fox occurs in southwest Baluchistan, in the northern hill region of Makran and north to Kharan $\left(28^{\circ} 35^{\prime} \mathrm{N} 65^{\circ} 25^{\prime} \mathrm{E}\right)$ and Kalat $\left(29^{\circ} 02^{\prime} \mathrm{N} 66^{\circ} 35^{\prime} \mathrm{E}\right)$. Specimens have been collected at Gwadar $\left(25^{\circ} 07^{\prime} \mathrm{N} 62^{\circ} 19^{\prime} \mathrm{E}\right)$, Turbat $\left(25^{\circ} 59^{\prime} \mathrm{N} 63^{\circ} 04^{\prime} \mathrm{E}\right)$, Chagai $\left(29^{\circ} 18^{\prime} \mathrm{N}\right.$ $\left.64^{\circ} 43^{\prime} \mathrm{E}\right)$ and Bajaur $\left(34^{\circ} 50^{\prime} \mathrm{N} 71^{\circ} 55^{\prime} \mathrm{E}\right.$; north Waziristan). There are no records of the species from the northern Himalayan range (Roberts, 1977). Hassinger (1973) reported that in Afghanistan Vulpes cana is only known from one location at Kandahar $\left(31^{\circ} 10^{\prime} \mathrm{N} 65^{\circ} 50^{\prime} \mathrm{E}\right.$; south Afghanistan). In Iran specimens were collected in the provinces of Fars $\left(29^{\circ} 00^{\prime} \mathrm{N}\right.$ $\left.53^{\circ} 00^{\prime} \mathrm{E}\right)$, Khuzistan $\left(30^{\circ} 30^{\prime} \mathrm{N} \quad 50^{\circ} 00^{\prime} \mathrm{E}\right)$ and Khorasan $\left(34^{\circ} 00^{\prime} \mathrm{N} 56^{\circ} 00^{\prime} \mathrm{E}\right)$. Lay (1967) observed one individual $8 \mathrm{~km}$ north of Persepolis ( $29^{\circ} 57^{\prime} \mathrm{N} 52^{\circ} 52^{\prime} \mathrm{E}$; Fars province) and found the remains of another near Ahmad
Mahamoudi $\left(28^{\circ} 15^{\prime} \mathrm{N} 53^{\circ} 36^{\prime} \mathrm{E}\right)$. Bobrinskii et al. (1965) reported that Vulpes cana in Russia is known from two locations near the border with north Afghanistan.

Specimens were collected in Bokhara ( $39^{\circ} 48^{\prime} \mathrm{N} 64^{\circ} 25^{\prime} \mathrm{E}$; Uzbekistan) and Germab ( $38^{\circ} 01^{\prime} \mathrm{N} 57^{\circ} 44^{\prime} \mathrm{E}$; Kopet Dagh Mt, Turkmeniya). Ranjitsinh (1984) observed from a helicopter two putative Blanford's foxes in the Great Rann of Kutch ( $27^{\circ} 00^{\prime} \mathrm{N} 70^{\circ} 00^{\prime} \mathrm{E}$; India). However, these animals were large and were located in a flat salt pan (M. K. Ranjitsinh, pers. comm.) so their identification is questionable.

Recently two specimens were trapped in Oman ( $17^{\circ} 12^{\prime} \mathrm{N} 54^{\circ} 55^{\prime} \mathrm{E}$; Jabal Samhan, Dhofar) and were later identified as Vulpes cana (Harrison and Bates, 1989). Gasperetti et al. (1985), in an account of the carnivores of Saudi Arabia, published a photograph (p. 405) of a fox that was identified as Vulpes vulpes arabica. The photo was taken in Wadi Khaytan $\left(19^{\circ} 45^{\prime} \mathrm{N} 41^{\circ} 42^{\prime} \mathrm{E}\right.$; western Saudi Arabia) at night. Walter Ferguson (pers. comm.) was the first to notice that in fact this animal is Vulpes cana. Other observers of Blanford's foxes in the wild and in captivity $(\mathrm{H}$. Mendelssohn, $\mathrm{Y}$. Yom-Tov and ourselves), share Ferguson's conclusion. Unfortunately, the end of the tail is not shown on the photograph, which creates some doubt (Harrison and Bates, 1989). Additional recent photographs of Blanford's foxes from Wadi Khaytan and the finding of a dead Blanford's fox $40 \mathrm{~km}$ south-east of Biljurshi, Asir province ( $\left.19^{\circ} 52^{\prime} \mathrm{N} 41^{\circ} 36^{\prime} \mathrm{E}\right)$ by $\mathrm{J}$. Gasperetti support Ferguson's initial identification (D. L. Harrison, pers. comm.). 


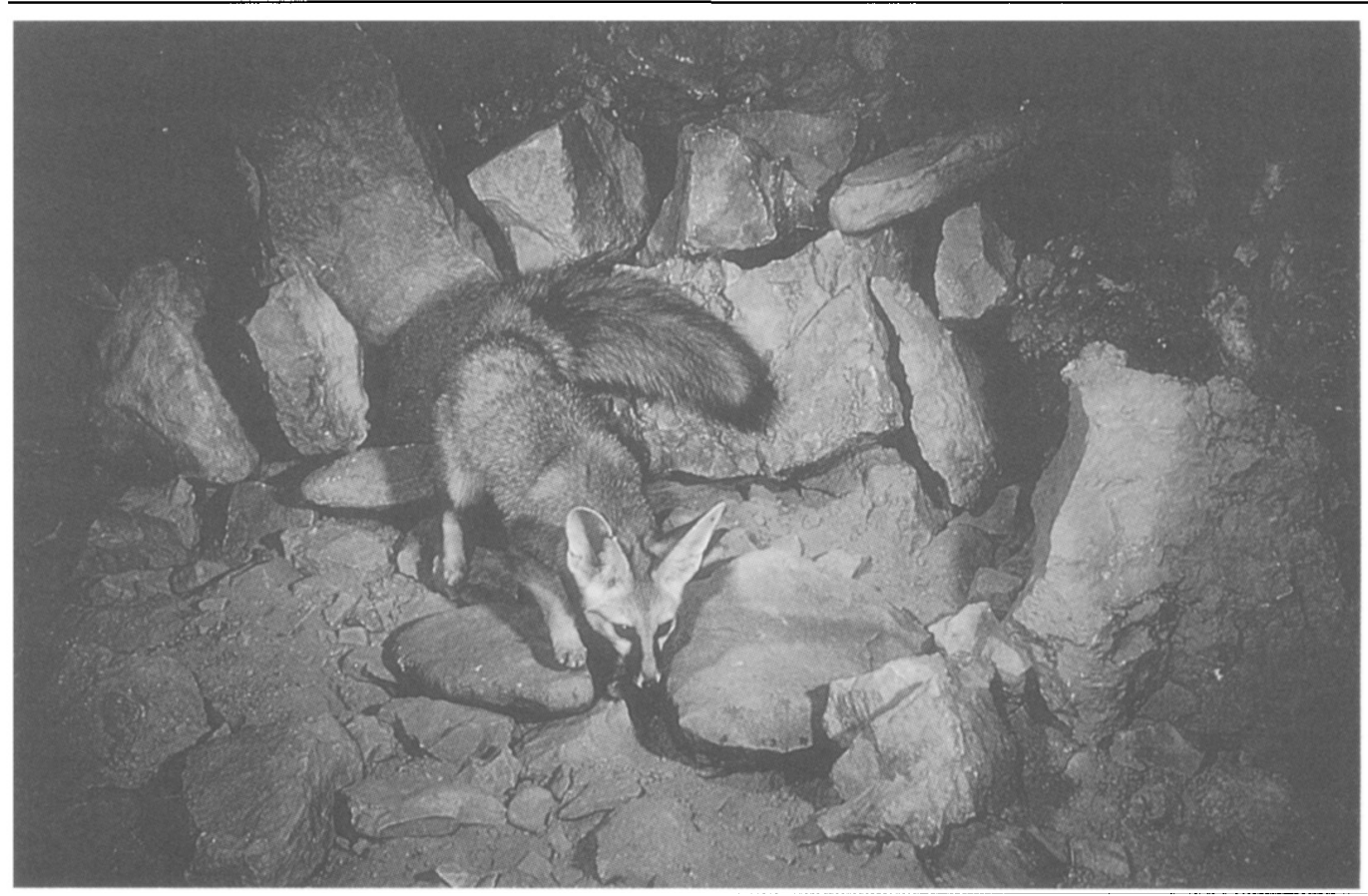

Blanford's fox in Israel (@ Steve Kaufman).

In Israel Blanford's fox was discovered at first near the oasis of Ein Gedi $\left(31^{\circ} 28^{\prime} \mathrm{N}\right.$ $\left.35^{\circ} 23^{\prime} \mathrm{E}\right)$ and later in Nahal Ze'elim $\left(31^{\circ} 20^{\prime} \mathrm{N}\right.$ $35^{\circ} 22^{\prime} \mathrm{E}$ ). Several other individuals were trapped in Makhtesh Ramon ( $30^{\circ} 38^{\prime} \mathrm{N} 35^{\circ} 00^{\prime} \mathrm{E}$ ) and near Eilat $\left(29^{\circ} 35^{\prime} \mathrm{N} 34^{\circ} 53^{\prime} \mathrm{E}\right)$ (llany, 1983; Mendelssohn et al., 1987). Mendelssohn et al. (1987) described an unsexed specimen that was collected in southern Sinai and had been misidentified as Vulpes ruppelli.

In all the publications that deal with the distribution of Vulpes cana in south-west Asia or the Middle East it is mentioned that the species is confined to mountainous regions. In south-west Asia Vulpes cana appears to be limited to the Persian plateau. Lay (1967) speculated that the species inhabits mountains throughout Iran. Hassinger (1973) concluded that Blanford's foxes are generally found below an altitude of $2000 \mathrm{~m}$, in dry montane biotopes. All south-west Asian records are from foothills and mountains in the vicinity of lower plains and basins (Hassinger, 1973; Roberts, 1977). Both Lay (1967) and Roberts (1977) described this species's habitat as comprising rocky mountainsides with stony plains and patches of cultivation. It appears to avoid higher mountain ranges as well as lower, warmer valleys (Roberts, 1977). In the Middle East the species is confined to mountainous desert ranges. Harrison and Bates (1989) and Mendelssohn et al. (1987) noted that Vulpes cana inhabits steep, rocky slopes and cliffs in Oman and Israel.

In the Canid Action Plan Ginsberg and Macdonald (1990) identified Blanford's fox as an unusual little-known canid, whose status merits close investigation. In the first systematic attempt to assess the status of this species we carried out a survey of Blanford's foxes in the desert regions of Israel and reviewed the available information on its distribution in an attempt to evaluate the basic needs for survival of this rare fox species.

\section{Methods}

We surveyed potential areas in Israel and Sinai for Blanford's foxes. We concentrated our trapping efforts in the southern and central Negev Desert mainly because of the lack 


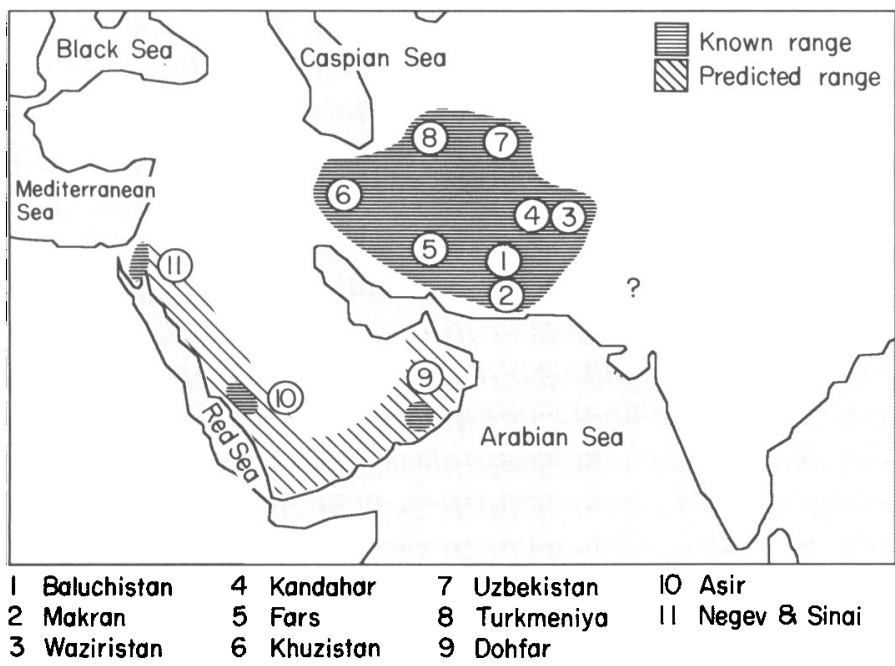

Figure 1. Distribution of Blanford's fox based on previous literature (heavy shading) and the predicted range in the Middle East (light shading). of casual observations from these regions. Census locations were chosen according to habitat suitability and water and vegetation availability.

Foxes were live-trapped using collapsible box traps (Tomahawk, $80 \times 22 \times 22 \mathrm{~cm}$ ). At each location four to six traps were set for 3-4 consecutive days and were checked and baited with fresh dead chicks daily. Traps were placed in canyons and on rocky slopes, usually under a large boulder in order to provide shade for trapped individuals. Trapped individuals were measured, weighed, individually marked with numbered metal ear tags and released. In addition, creekbeds and mountain slopes were combed for the unmistakably small tracks of the Blanford's fox. Fox carcasses that were occasionally found by hikers and brought to us provided additional information.

\section{Results}

The distribution of Blanford's fox based on the present literature is shown in Figure 1. The results of our survey in Israel are presented as a distribution map of the species (Figure 2). We considered sites with Blanford's foxes as sites where individuals were trapped, observed or their tracks identified by an authorized person. Sites where Blanford's foxes were recorded during this study included: Ma'ale Enmar, upper Nahal Geled, and upper Nahal Neqarot in the central Negev Desert; and Nahal Qetura, Nahal Yotvata, Timna valley, Nahal Eteq, Har Shehoret and Nahal Netafim in the southern Negev Desert (Figure 2). No foxes were trapped in the lower Nahal Neqarot $\left(30^{\circ} 39^{\prime} \mathrm{N} 35^{\circ} 05^{\prime} \mathrm{E}\right)$, Nahal Karkeshet (30 $\left.38^{\prime} \mathrm{N} 35^{\circ}{ }^{\prime} 0^{\prime} \mathrm{E}\right)$, Nahal Divshon (30 $\left.50^{\circ} \mathrm{N} 34^{\circ} 47^{\prime} \mathrm{E}\right)$ and upper Nahal Zin $\left(30^{\circ} 50^{\prime} \mathrm{N} 34^{\circ} 46^{\prime} \mathrm{E}\right)$, in the central Negev and Nahal Argaman $\left(29^{\circ} 52^{\prime} \mathrm{N}\right.$ $\left.35^{\circ} 02^{\prime} \mathrm{E}\right)$, Nahal Qadqad $\left(29^{\circ} 49^{\prime} \mathrm{N} 34^{\circ} 58^{\prime} \mathrm{E}\right)$ and Nahal Gadna $\left(29^{\circ} 43^{\prime} \mathrm{N} 34^{\circ} 58^{\prime} \mathrm{E}\right)$ in the southern Negev, although the habitat in these sites appeared to be suitable.

Foxes could not be trapped freely in Sinai due to international borders, but we collected one specimen from Jabel Umm-Shawmar $\left(28^{\circ} 22^{\prime} \mathrm{N} 33^{\circ} 55^{\prime} \mathrm{E}\right.$, southern Sinai; permanent springs; magmatic rock) and found many tracks in Wadi Isla $\left(28^{\circ} 20^{\prime} \mathrm{N} 34^{\circ} 00^{\prime} \mathrm{E}\right.$; permanent springs; magmatic rock).

\section{Discussion}

The present distribution pattern of Blanford's fox suggests that the species has a much larger range than was believed earlier. Mendelssohn et al. (1987) noted that the species is unlikely to be found in the open, flat deserts of Syria and Iraq. From the few records available to date, 
we expect that Vulpes cana will be found to occur continuously from Iran to Jordan and Israel, following the marginal west and south zones of the Arabian peninsula. Mountain ridges crossing Muskat, Oman, Yemen and running parallel with Saudi Arabia's west coast provide an ideal and continuous habitat.

Figure 2. Distribution of Blanford's fox in Israel. Each number corresponds to a site at which specimens were observed or trapped, or where identifiable remains were found.

Broken lines represent international borders. 1. Ein Duyuk (spring; limestone; Isr. L. Nat. 1987. 12 (4), 169; dead specimen), 2. Wadi Qelt (stream; limestone; Isr. L. Nat. 1987. 12 (4), 169; dead specimen), 3. Nahal Qumran (no water; limestone; NRA (D. Nisim); observation), 4. Nahal Qidron (stream; limestone; NRA (D. Nisim); observation), 5. Nahal Mashash (rock pools; limestone; this study (Y. Timna); dead specimen), 6. Ein Gedi (streams, springs; limestone; Ilany, 1983, this study; trapping), 7. Nahal Hever (small spring; limestone; NRA (A. Oren); observation), 8. Nahal Ze' elim (springs; limestone; Isr. L.Nat. 1984. 9(4), 170-171; trapping), 9. Nahal Boqeq (stream; limestone; TV. 1985. 27(2), 38; observation), 10. Nahal Peres (no water; limestone; Isr. L. Nat. 1985. 10(4),166; dead specimen), 11.

Nahal Hatira (spring; limestone; TV 1982. 24(4),186; dead specimen), 12. Ein Yahav (settlement; limestone; Isr. L. Nat. 1984. 9(4), 170-171; dead specimen). 13. Ein Avedat (springs; limestone; Isr. L. Nat. 1988. 13(4), 198; dead specimen), 14. Nahal Darokh (no water; limestone; Isr. L. Nat. 1986. 11(4), 194; observation), 15. Ein Marzeva (spring; limestone; TV 1983. 25(6), 45-46; tracks), 16. Ma'ale Enmar (no water; limestone; this study; trapping), 17. Nahal Holit (no water; limestone; NRA (G. Ilany) and this study; trapping), 18. Nahal Geled (spring; limestone; this study; trapping), 19. Nahal Neqarot (spring; limestone; this study; trapping), 20. Nahal Qetura (no water; limestone - sandstone; this study; dead specimen), 21. Nahal Yotvata (no water; limestone - sandstone; this study; dead specimen), 22. Timna valley (no water; limestone - sandstone; this study; trapping), 23. Nahal Eteq (rock pools; limestone - sandstone; this study; tracks) 24. Har Shehoret (no water; limestone - sandstone; this study; trapping), 25. Nahal Netafim (spring; limestone - sandstone; this study; trapping), 26. Nahal Gishron (no water; magmatic rock; Isr. L. Nat. 1983. 9(1), 39; tracks). In parentheses: type of water source, type of rock in the site, reference and the means of identification. Isr. L. Nat.=Israel Land and Nature. TV $=$ Teva va-Aretz (in Hebrew).

NRA=Nature Reserves Authority Data Centre.
The species's apparently patchy distribution in the Middle East is probably due to our lack of information. The Blanford's foxes' elusive habits and inaccessible habitat make them hard to detect. It is possible that in the future this fox will be found in north-west India and along the western Red Sea shore south to Ethiopia. These areas offer suitable habitat and weather and are not separated by any barriers that could not have been crossed during the past ice ages.

In Israel, the distribution of Blanford's fox coincides with the west side of the Rift Valley.

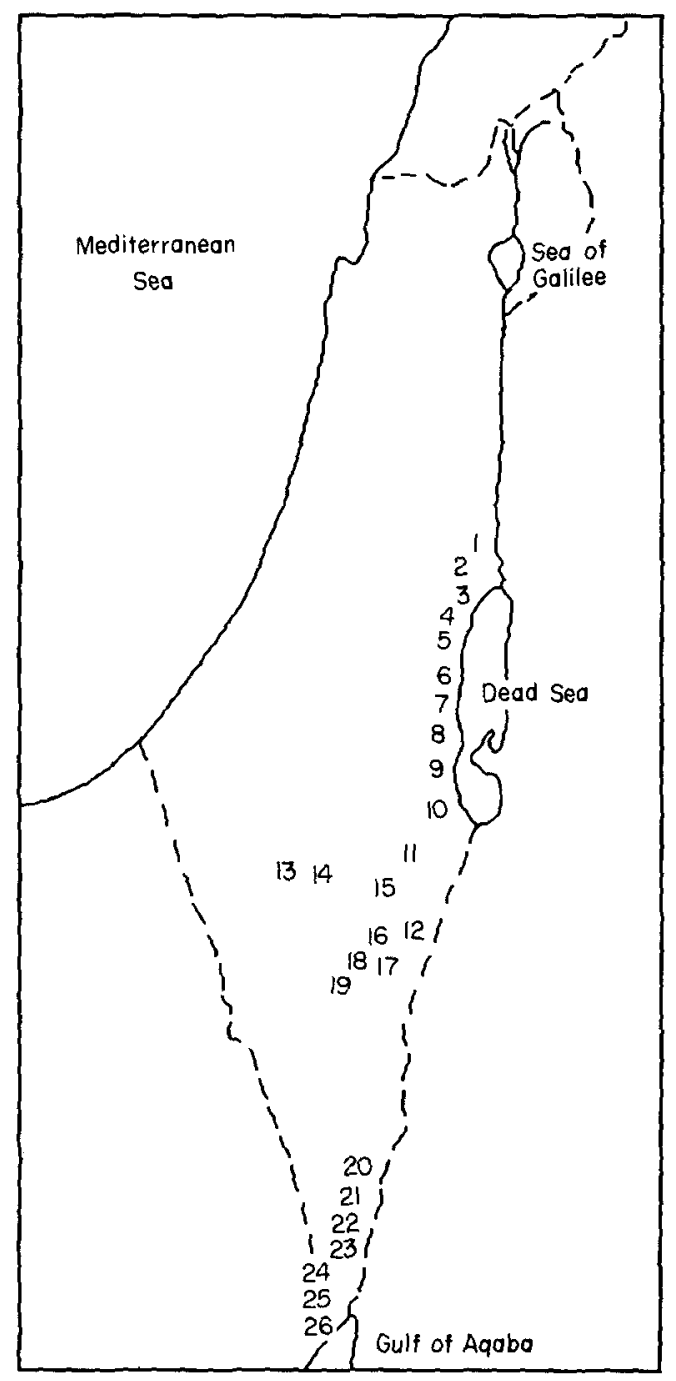


In the central Negev, specimens were collected in creeks that lead back to the Rift Valley. Apparently, Vulpes cana can occur on various rock types as long as the location meets its other requirements (Figure 2). The presence of water in the immediate vicinity does not appear to be very important. At all locations listed in Figure 2 rock pools filled by heavy rain last from a few weeks to up to several months in winter. In Israel Vulpes cana occurs in the driest and hottest regions and is largely insectivorous (Geffen et al., 1992). The densest population is found in the Judaean Desert, the lowest valley on earth. This is at odds with Roberts's (1977) remark that the species in Pakistan avoids low, warm valleys.

In conclusion, Blanford's fox probably originated in the Iranian plateau, which is characterized by cold winters, very hot summers and extreme aridity. The spread of the species into the Middle East apparently followed routes and areas that provided similar habitat and ambient conditions. What are the implications of our findings to the conservation of the species? Our survey showed that in Israel Blanford's fox is a common desert carnivore, although its distribution is restricted to a specific habitat type. In Israel, most of its range lies within nature reserves. Although the future survival of Blanford's foxes in Israel seems secure, this area is only a fraction of its entire range. We urge those involved in the planning of protected areas in Saudi Arabia and Oman to consider Blanford's foxes in selecting mountainous desert areas for conservation. Additional surveys for Blanford's foxes in the Middle East are necessary to provide a more complete assessment of the distribution of this specialized canid. While the cliff-side habitat of the species is little disturbed by people and thus may be relatively easy to conserve, the fact that the habitat-type has a restricted distribution means that this fox will inevitably be uncommon.

\section{Acknowledgments}

We wish to thank Professor Y. Yom-Tov for providing box traps and other equipment. The project was supported and funded by the Nature Reserves
Authority of Israel, the Fauna and Flora Preservation Society and the People's Trust for Endangered Species, and represents a contribution to the work of the IUCN/SSC Canid Specialist Group.

\section{References}

Bobrinskii, N.A., Kuznecov, B.A. and Kuzyakin, A.P. 1965. Synopsis of the Mammals of USSR. Moscow.

Gasperetti, J., Harrison, D.L. and Buttiker, W. 1985. The carnivores of Arabia. Fauna of Saudi Arabia, 7, 397-461.

Geffen E., Hefner R., Macdonald D.W. and Ucko M. 1992. Diet and foraging behaviour of Blanford's foxes in Israel. J. Mammal. 73 (2), 395-402.

Ginsberg, J.R. and Macdonald, D.W. 1990. Foxes, Wolves, Jackals and Dogs: An Action Plan for the Conservation of Canids. IUCN, Gland, Switzerland.

Harrison, D.L. and Bates, P.J.J. 1989. Observations on two mammal species new to the Sultanate of Oman, Vulpes cana Blanford, 1877 (Carnivora: Canidae) and Nycteris thebaica Geoffroy, 1818 (Chiroptera: Nycteridae). Boon. Zool. Beitr. 40, 73-77.

Hassinger, J.D. 1973. A survey of the mammals of Afghanistan. Fieldiana. Zoology. 60. Field Museum of Natural History, Chicago.

Ilany, G. 1983. Blanford's fox, Vulpes cana, Blanford 1877, a new species to Israel. Isr. I. Zool. 32, 150.

Lay, D.M. 1967. A study of the mammals of Iran. Fieldiana. Zoology. 54. Field Museum of Natural History, Chicago.

Mendelssohn, H., Yom-Tov, Y., Ilany, G. and Meninger, D. 1987. On the occurrence of Blanford's fox, Vulpes cana, Blanford, 1877, in Israel and Sinai. Mammalia, 51, 459-462.

Ranjitsinh, M.K. 1984. A possible sighting of Blanford's fox (Vulpes cana) in Kutch. J. Bombay Nat. Hist. Soc. 82, 395-396.

Roberts, T.J. 1977. The Mammals of Pakistan. Ernest Benn Limited, London.

Eli Geffen, Wildlife Conservation Research Unit, Department of Zoology, South Parks Road, Oxford. OX1 3PS, UK. Present address: c/o Dr Robert Wayne, Department of Biology, 621 Circle Dr., University of California. Los Angeles, CA 900241606, USA.

Reuven Hefner, Nature Reserves Authority, P.O.Box 677, Eilat, Israel.

David W. Macdonald, Wildlife Conservation Research Unit, Department of Zoology, South Parks Road, Oxford OX1 3PS, UK.

Michal Ucko, IOLR, National Center for Marine Culture, PO Box 1212, Eilat, 88112, Israel. 